Research Article

\title{
Evaluation of Soil Drainage Methods for the Productivity of Waterlogged Vertisols in Jama District, Eastern Amhara Region, Ethiopia
}

\author{
Muluken Lebay $\left(\mathbb{D}\right.$, Wudu Abiye $\left(\mathbb{D}\right.$, Tilahun Taye $\mathbb{D}^{D}$, and Seid Belay ${ }^{\mathbb{C}}$ \\ Sirinka Agricultural Research Center, Sirinka, Weldiya, Ethiopia \\ Correspondence should be addressed to Muluken Lebay; mulerbruk2016@gmail.com
}

Received 16 February 2021; Revised 19 May 2021; Accepted 17 June 2021; Published 24 June 2021

Academic Editor: Othmane Merah

Copyright (c) 2021 Muluken Lebay et al. This is an open access article distributed under the Creative Commons Attribution License, which permits unrestricted use, distribution, and reproduction in any medium, provided the original work is properly cited.

\begin{abstract}
Vertisols are important agricultural soils in the Ethiopian highlands. The highland part of the Jama district is one of which Vertisols have huge coverage and are underutilized due to waterlogging. Such potential Vertisol areas need to be put under wise cultivation. Thus, a study was conducted to investigate the effects of soil drainage methods on surface runoff, soil loss, and yield of wheat crop as indicators of productivity improvement of typical Vertisol in the Jama district of Amhara Region, Ethiopia, during the rainy season of 2017/18. The treatment comprised three soil drainage methods (BBF120, BBF80, and BBF40) arranged in a randomized complete block design with three replications on standard runoff plots. Statistical Analysis System, version 9.0, was used to perform analysis of variance and mean separation of the collected data on yield, soil loss, and runoff. The result indicated that the effect of BBF120 brought significantly $(P<0.05)$ higher difference on surface runoff, yield, and biomass of wheat over BBF40. The rainfall of about $55.05 \%, 51.45 \%$, and $48.07 \%$ was lost as runoff from BBF120, BBF80, and BBF40, respectively. Drainage method BBF120 gave $34.6 \%$ and $17.3 \%$ of grain yield advantage over the drainage methods of BBF40 and BBF80, respectively, whereas soil loss was not significantly $(P>0.05)$ different among all treatments; it is still in the range of soil loss tolerance in Ethiopia. As enhanced drainage is a requirement for successful crop production on Vertisol areas, BBF120 is recommended for draining excess runoff and consequently maximizing the yield of wheat in the study area and others with a similar farming system and agroecology.
\end{abstract}

\section{Introduction}

In Ethiopia, about 12.6 million hectares of land are reported as Vertisol; it accounts for the portion of about $10 \%$ of the total area of the country and is almost constrained by the waterlogging problem due to the excess rainfall during the main growing seasons [1-3]. The highland location where rainfall is plenty coupled with relatively noble inherent fertility status enables these soils to have great potential for crops. Vertisols are some of the most productive soils for rainfed agriculture. Their high water holding capacity allows them to compensate better than most other soils for the low and erratic rainfall. On the contrary, due to the integral physical characteristics of these soils together with high rainfall, concentrated on months from June to September, the yield of wheat is low mainly due to waterlogging. Old data showed that out of the 7.6 million hectares of Vertisols found in the highlands, only $26 \%$ of this area was under cultivation mainly due to waterlogging, the difficulty of land preparation and soil erosion [3-5]. The traditional drainage system in Vertisol areas mainly enables the development of rills and gullies during heavy rainfall, and it ultimately leads the land to be dissected here and there. According to Amsalu and De Graaff [6] and Bewket [7], soil erosion, as a result of inappropriate land-use systems and erratic and high-intensity rainfall, takes a huge part for the degradation of the Ethiopian highlands. Gully erosion is a widespread phenomenon in the Ethiopian highlands leading to high sediment loads in rivers [8]. Vertisols take a significant share of productive agricultural soils in the Ethiopian highlands, but 
it is challenging to achieve the expected level of production due to their poor internal drainage and subsequent waterlogging [9]. The highland part of the Jama district is one of which Vertisols have huge coverage and are underutilized due to waterlogging. It is long established that waterlogging results in poor aeration, lower soil microbial activities, loss and unavailability of plant nutrients, and poor workability; in turn, it causes Vertisols in Ethiopia to be underutilized. In swamplands, the soil pores inside the root zone of crops are saturated, and air circulation is closed. Waterlogging, therefore, precludes the free circulation of air within the root zone. Thus, water work adversely affects the chemical processes and also the bacterial activities that are essential for the correct growth of a plant [10] cited by Assen et al. and Mekonen et al. [11, 12]. McDonald and Gardner [13] reported that the water table reaches near the root zones of the crops as a result of waterlogging which will cause the soil pores to become fully saturated, the normal circulation of air in the root zones of the crops has stopped, and the growth of the crops decreased. The root tips, where most water, air, and nutrient uptake take place, are the first to suffer from waterlogging mainly due to the lack of oxygen, reducing the seminal root growth, in particular. Consequently, the crop root zone is poorly aerated, and nutrient uptake for growth and development will be impaired [14]. To overcome the waterlogging stress, farmers in the highlands of eastern Amhara adopt a drainage technology called broad bed and furrow (BBF), but using this technology, they plant late in the season around the end of August up to mid-September when excess water naturally drained away so that the crops grow on residual moisture; however, planting late in the season has yield disadvantage as the crop would be exposed to terminal moisture stress and frost damage $[9,15]$ In good years (if the rain extends to September and October), the harvest may be very good if there is no frost. However, as this often fails, the consequence can range from substantial yield reduction to total crop failure [2]. In high-rainfall areas, it is common to make ridges and furrows using the traditional plowing implement "Maresha" at an interval of 40 to $60 \mathrm{~cm}$. Using Maresha, farmers in Ethiopia are able to disturb the soil, lift it, and turn it equally on each side of the plow, leaving a narrow furrow for water drainage and two small ridges behind to grow crops. In this traditional ridge and furrow system, the furrows take up $40-50 \%$ of the crop area [16]. Crop production and livestock feeding have been pushed by an increasing population pressure to steep slopes in the way of causing serious devegetation and soil erosion, while Vertisols remain underutilized. There is a big opportunity to meet the demand of food for the doubling population if management strategies could be implemented towards the novel Vertisols with large moisture-holding capacity and relatively high fertility [17]. In Ethiopia, where the people are suffering from food scarcity, removing production constraints in Vertisol areas is significantly an important alternative [18]. Vertisol which covers an enormous landmass of the country needs to be put under cultivation with excess water draining innovations to achieve food security in Ethiopia. Furthermore, it has been reported that the removal of excess water from Vertisol significantly enhances nutrient uptake in crops [19]. It is also proved that substantial increases in crop yield could be obtained on Vertisols if excess surface soil water is drained off and if appropriate cropping practices are used [17]. Therefore, this study was conducted to investigate the effects of soil drainage methods on (i) enhancing surface drainage as an indicator of improved productivity through making an effective ridge and furrow system, (ii) soil loss as indicators of the extent of soil degradation, and (iii) runoff generation for further discoveries related with water management to improve the productivity of typical Vertisol in the highland area.

\section{Materials and Methods}

2.1. Description of the Study Area. The experiment was conducted during the main rainy seasons from 2017 to 2018, in the Jama district of the South Wollo administrative zone of the Amhara national regional state in the northeastern highland Vertisol area of Ethiopia at the research station of the Sirinka Agricultural Research Center, which is $362 \mathrm{~km}$ northeast from Addis Ababa (Figure 1). Geographically, the district is located between $10^{\circ} 06^{\prime} 24^{\prime \prime}$ to $10^{\circ} 35^{\prime} 45^{\prime \prime} \mathrm{N}$ latitude and $39^{\circ} 04^{\prime} 04^{\prime \prime}$ to $39^{\circ} 23^{\prime} 03^{\prime \prime} \mathrm{E}$ longitude with an altitude of 2850 masl at the specific area of a research station (Figure 1).

Based on the 10-year (2008-2018) climatic data, the area receives an average annual rainfall of $1012.0 \mathrm{~mm}$ of which $74.6 \%$ is received during the main rainy season (June to September), and the highland plateau of Jama has a very cold temperature which ranges from 0 to $20^{\circ} \mathrm{C}$. The dominant soil in Jama is Vertisol which is black to gray clay with high swelling and shrinking characters. It is poorly drained when wet and cracking when dry. The land use is mostly cultivated field crops: wheat (Triticum aestivum L.), teff (Eragrostis tef L.), and faba bean (Vicia faba L.) in rotation, while the marginal lands along the roadsides and communal pasture lands purposely left for feed sources are the major grazing grounds [20].

2.2. Treatments and Experimental Design. Treatments (Table 1) of three soil drainage methods/planting beds were arranged in a randomized complete block design (RCBD), with three replications on plots having a size of $4.8 \mathrm{~m}$ width and $10 \mathrm{~m}$ length dimensions of the measurable runoffproducing area.

BBF120: this system was constructed manually through scooping the soil from two sides of the furrows and distributing evenly on the upper part of the bed after the land is plowed by the traditional ox-drawn tine-plow implement having $40 \mathrm{~cm}$ width. The effective growing area is $120 \mathrm{~cm}$ wide and $20 \mathrm{~cm}$ high, separated by $40 \mathrm{~cm}$-wide furrows, to facilitate surface drainage between the beds. The crops are sown at the beginning of July, depending on the onset of rain and the type of crop to be grown.

BBF80: this was made with an effective bed width of $80 \mathrm{~cm}$ and $40 \mathrm{~cm}$ wide and $20 \mathrm{~cm}$ deep drainage furrows. 

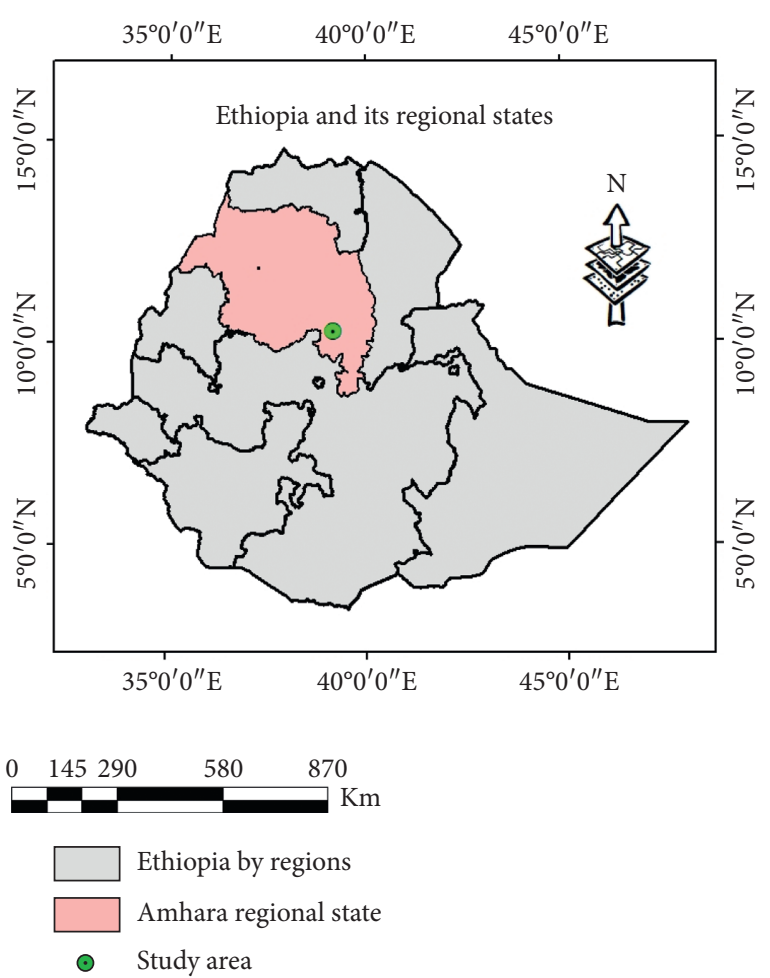

FIGURE 1: Location of the study area at Jama district in northeastern Ethiopian highlands.

TABle 1: Treatments' description.

\begin{tabular}{lc}
\hline Treatment name & Remark \\
\hline BBF120 & $120 \mathrm{~cm}$ bed width and $40 \mathrm{~cm}$ furrow width \\
BBF80 & $80 \mathrm{~cm}$ bed width and $40 \mathrm{~cm}$ furrow width \\
BBF40 & $40 \mathrm{~cm}$ bed width and $40 \mathrm{~cm}$ furrow width \\
\hline
\end{tabular}

NB: use this table for further identification of treatments in all sections of the paper.

This land preparation method is a recommended surface drainage system for Ethiopian highland Vertisol areas.

BBF40: this is a traditional soil drainage method in the study area and neighbor districts of northeastern highland Vertisol of Ethiopia for crops susceptible to waterlogging. It is constructed with the traditional tine plow after the seed is broadcast with an effective bed width of $40 \mathrm{~cm}$ and $40 \mathrm{~cm}$ wide and $20 \mathrm{~cm}$ deep drainage furrows so that the crops grow on the ridges, allowing excess water to drain out of the field through the furrows. In the case of our experiment, it was considered as a conventional drainage method of the local farmers, while planting techniques and inputs were applied based on the recommended packages for the area.

2.3. Runoff, Soil Loss, and Moisture Content Measurements. Nine hydrologically isolated runoff plots of $10 \mathrm{~m}$ long and $4.8 \mathrm{~m}$ wide $\left(48 \mathrm{~m}^{2}\right)$ were delineated on uniform land, and the beds and furrows were graded along the slope to facilitate surface drainage through the furrows between the beds so that the crops grow on the drained beds. Plots were bounded by a galvanized metal sheet of $50 \mathrm{~cm}$ depth, of which $25 \mathrm{~cm}$ was inserted into the ground to prevent the lateral flow of runoff, and the rest was above the ground to block overland flow from entering the experimental plot. At the lower side of each plot, a water collector channel was constructed to collect water drained from the furrows and beds (Figure 2). This water collector channel was also integrated with a small sediment trap (micropond) excavated at the outlet on which a barrel-like cylindrical tube was installed to measure the amount of runoff generated and soil removed from each drainage technique/treatment. The rain gauge was installed near the experimental plots to record daily rainfall of the area.

Runoff was measured through using multislot divisors in a way that surface runoff was collected in the first tank, and $10 \%$ of runoff that overflowed from the first tank was received by the second tank. The amount of runoff and sediment load from each tank was measured daily (at 9:00 AM), and then the total daily and annual runoff amount for all the rainy days in a year per treatment for the main rainy season (keremit) was calculated as a ratio of runoff volume $\left(\mathrm{m}^{3}\right)$ to the area of runoff plot $\left(48 \mathrm{~m}^{2}\right)$ and then converted into equivalent rate in a hectare of land. Similarly, the runoff coefficient was calculated as the percentage of daily runoff $(\mathrm{mm})$ to daily rainfall $(\mathrm{mm})$. The total amount of eroded soil was determined through filtration (paper type: Whatman-597, with a pore size of 4-7 $\mu \mathrm{m}$ ) of composite samples collected from both tanks after thoroughly mixing the collected runoff and sediment (Figure 3). After filtration, the remaining sediment was ovendried at $105^{\circ} \mathrm{C}$ for 24 hours and then weighed and compared with the weight of another filter paper of the same size as a control to estimate the daily average soil loss from each replicated treatment as per the respective total runoff measured in the area [21]. Soil moisture data were also taken through the gravimetric method starting from mid-August onward at three positions of the bed with a depth of $0-30 \mathrm{~cm}$, and finally, the average data were presented. It was helpful to observe whether there is a difference in the water content of the soil for different drainage methods with respective amount of runoff drained out.

2.4. Agronomic Practices and Data Collection. Tillage practices were applied 3 times a year on this area. The first plowing was done during the short rainy season, from March to May; and the secondary and tertiary tillage operations were undertaken at the mid of June to the end of June, respectively. All beds and ridges were prepared in the first week of July at the first rain shower when the soil becomes moist for the ease of cultivation because the soil at this time is not bulky (not heavy) for bed preparation. Wheat (Triticum aestivum $\mathrm{L}$.) was used as a test crop to evaluate the effect of soil drainage methods on runoff, soil loss, and wheat yield. The seeding rate of wheat (variety sora) at a rate of $150 \mathrm{~kg} \cdot \mathrm{ha}^{-1}$ was applied in a row. Recommended fertilizer rates for the area $\left(115 \mathrm{~kg} / \mathrm{ha} \mathrm{N}\right.$ and $\left.69 \mathrm{~kg} / \mathrm{ha} \mathrm{P}_{2} \mathrm{O}_{5}\right)$ were applied for all treatments, and hand weeding was used to control weeds. Agronomic data such as plant height, biomass, and grain yield were taken from the respective experimental plots through excluding border effects. For the 


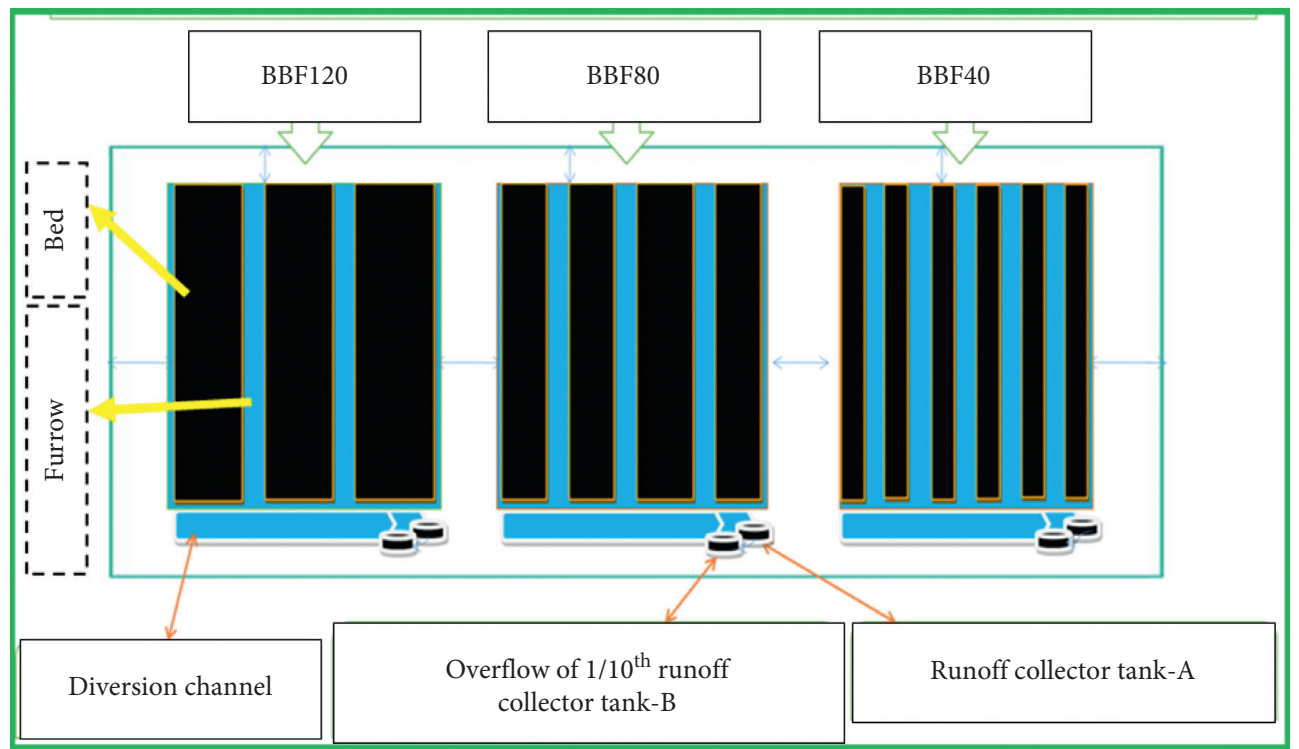

FIgURE 2: Field layout of the experiment.

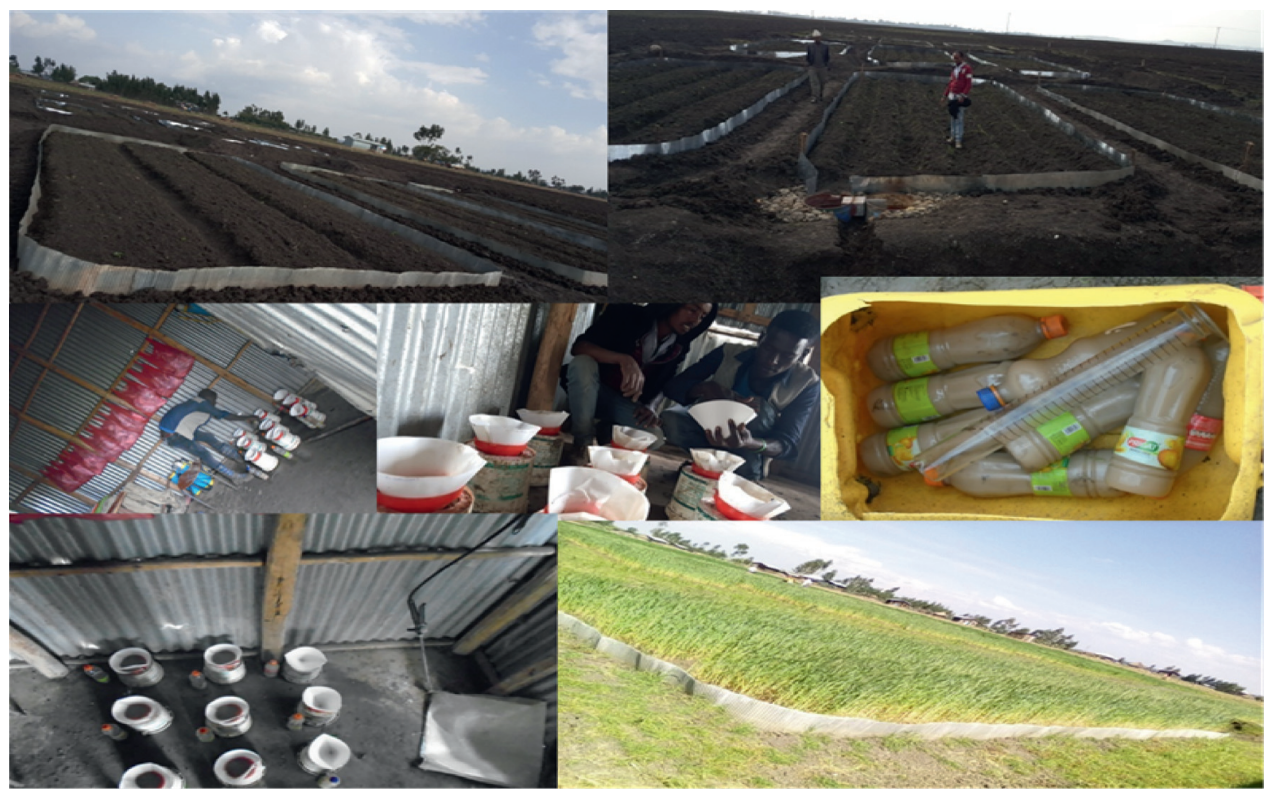

FIgURE 3: Land preparation, water sample collection, and sediment filtration process.

plant height data, five plants were randomly selected from the entire plot to measure their height and then continue for each of three replicated experimental plots. Finally, the measured height was summarized in its average value, whereas grain yield and biomass data were recorded from the net plot in different treatments. Then, wheat grain yield was further adjusted with $12.5 \%$ standard grain moisture of cereal crops using the grain moisture analysis computer.

2.5. Data Analysis. The data from each of the two years separately and altogether were statistically analyzed to understand the effect of drainage methods on runoff, soil loss, and wheat yield. Microsoft Office Excel 2010 and SAS version 9.0 were used to analyze the data. Analysis of variance (ANOVA) was performed to test whether the changes in runoff, soil loss, and wheat yield induced by treatments were statistically significant. Mean values were compared with the LSD test at $P<0.05$.

\section{Results and Discussion}

3.1. The Effect of Soil Drainage Methods on Surface Runoff. The total rainfall received during the rainy seasons of 2017 and 2018 was $503.4 \mathrm{~mm}$ and $558.7 \mathrm{~mm}$, respectively (Table 2). From the total amount of rainfall received, $54.09 \%$ and $55.91 \%$ from BBF120, 52.52\% and 50.49\% from BBF 80 , and $47.57 \%$ and $48.58 \%$ from BBF40 were converted to runoff for the 2017 and 2018, respectively (Table 2). In comparison 
TABLE 2: Rainfall (mm), runoff (mm), runoff coefficient (\%), and sediment yield analysis results during the growing periods with their combined mean.

\begin{tabular}{|c|c|c|c|c|c|c|c|c|c|}
\hline \multirow{2}{*}{ Treatments } & \multicolumn{3}{|c|}{2017} & \multicolumn{3}{|c|}{2018} & \multicolumn{3}{|c|}{ Combined } \\
\hline & RO & $\mathrm{RC}$ & Sed & RO & $\mathrm{RC}$ & Sed & RO & $\mathrm{RC}$ & Sed \\
\hline BBF120 & $272.27^{\mathrm{a}}$ & 54.09 & 8.09 & $312.37^{\mathrm{a}}$ & 55.91 & 10.04 & $292.32^{\mathrm{a}}$ & 55.05 & 9.12 \\
\hline BBF80 & $264.38^{\mathrm{a}}$ & 52.52 & 8.04 & $282.10^{\mathrm{b}}$ & 50.49 & 9.23 & $273.20^{\mathrm{ab}}$ & 51.45 & 8.64 \\
\hline BBF40 & $239.47^{b}$ & 47.57 & 6.08 & $271.40^{\mathrm{b}}$ & 48.58 & 8.83 & $255.30^{\mathrm{b}}$ & 48.07 & 7.45 \\
\hline Std & 17.12 & 3.40 & 1.15 & 21.25 & 3.80 & 0.62 & 18.51 & 3.49 & 0.86 \\
\hline CV (\%) & 11.60 & - & 14.53 & 9.14 & - & 7.40 & 12.12 & - & 17.52 \\
\hline $\operatorname{LSD}(\alpha=5 \%)$ & 15.06 & - & NS & 57.27 & - & NS & 23.79 & - & NS \\
\hline $\mathrm{RF}$ & & 503.40 & & & 558.70 & & & 531.05 & \\
\hline
\end{tabular}

RO: runoff; RC: runoff coefficient; Sed: sediment; RF: rainfall; NS: not significant. Different superscript letters represent significant differences $(P<0.05)$, whereas means followed by the same letter are not significantly different $(P>0.05)$.

with BBF120, the lowest runoff coefficient for the years 2017 and 2018, respectively, was recorded from BBF40. This might be attributed to the reduced speed of runoff from the ridge and furrow system due to flat and uniform slopes, which have resulted in higher opportunity time for infiltration or evaporation from depression storage on created furrows [22]. The runoff coefficient from all treatments was not significantly varied in both years of the study periods. The periodical data in Figures 4 and 5 indicated that the drainage methods' tendency to drain out excess water is clearly shown when rainfall intensity becomes higher. Though aggressive soil loss is not observed in the experiment, it highly looks proportional with the runoff generated from the field. As shown in Table 2, there have been statistically significant differences $(P<0.05)$ among the treatments in terms of surface runoff.

In 2017, surface runoff was highest in BBF120 $(272.27 \mathrm{~mm})$ and BBF80 $(264.38 \mathrm{~mm})$; however, the lowest $(239.47 \mathrm{~mm}$ ) runoff was recorded from BBF40. In 2018, alike in 2017, the highest surface runoff $(312.37 \mathrm{~mm})$ was obtained from BBF120 and the lowest from BBF80 $(282.10 \mathrm{~mm})$ and BBF40 $(271.40 \mathrm{~mm})$. The two-year average surface runoff was significantly highest $(292.32 \mathrm{~mm})$ in BBF120 and the lowest $(255.30 \mathrm{~mm})$ from BBF40. The research finding is in contrast with Mekonen et al. [12] who showed the ridge and furrow system drained excess water out of the field due to a large number of furrows constructed on the land that can naturally drain water with a bit provision of furrows. Although the artificial drainage density was relatively higher in BBF40, increased volume of runoff was shown from BBF120. This situation could be attributed to reduced surface storage capacity from the experimental plots of BBF120 because the surface was relatively smooth and flat that allows water to be stagnated in the furrows than being disposed. Traditionally, surface roughness is created through the tillage/ridge and furrow system which forms microdepressions in which excess water is stored [23-25]. Unlike the case of Mekonen et al. [12], these large numbers of microdepressions created by the RF method coupled with a flat slope allow water to be stored along the channel instead of draining out. On the contrary, BBF with a large bed size and a small number of furrows could significantly enable the runoff to be drained from relatively large catchment to furrows widely spaced, and it gets the energy to flow out of the plot through powerful concentration on the channels. The runoff coefficient for all the treatments and, particularly, for BBF120 was substantial. Our finding is in line with other studies that BBF with large bed size induced more surface runoff than BBF with small bed size at flatlands in the highlands of Ethiopia [15]. To solve the problem of crop failure due to moisture stress and to avoid losses of soil and nutrients, changing this water resource into production through supplementary irrigation and other purposive techniques needs to be explored.

3.2. The Effect of Soil Drainage Methods on Soil Loss. The effect of drainage methods on soil loss is presented in Table 2 for an annual basis of the two consecutive years (2017 and 2018) and the mean. As shown in Figures 4 and 5, though the recorded amount of soil loss showed a direct proportional trend with runoff, statistically nonsignificant difference was observed $(P>0.05)$ between treatments in both years including the mean. The finding indicated that soil loss showed an increment tendency corresponding to the runoff in both 2017 and 2018 growing seasons for all treatments. Unlike the runoff, the effects of the treatments on soil loss were not statistically significant in all years $(P>0.05)$ between each treatment, but numerically, highest soil loss $\left(9.12 t \cdot \mathrm{ha}^{-1}\right)$ was recorded in BBF120 and the lowest $\left(7.45 t \cdot \mathrm{ha}^{-1}\right)$ from BBF40 (Table 2) on an average basis. The soil amount eroded from all treatments in 2018 is relatively higher compared with the year 2017 due to the highest proportional extent of runoff generated in 2018 as well. Two-year combined analysis result of soil loss from all drainage methods $\left(9.12 t \cdot \mathrm{ha}^{-1} \cdot \mathrm{yr}^{-1}\right.$, $8.64 t \cdot \mathrm{ha}^{-1} \cdot \mathrm{yr}^{-1}$, and $\left.7.45 \mathrm{t} \cdot \mathrm{ha}^{-1} \cdot \mathrm{yr}^{-1}\right)$ is in the range of soil loss tolerance in Ethiopian highlands $\left(2-10 t \cdot \mathrm{ha}^{-1} \cdot \mathrm{yr}^{-1}\right)$ [26]. This eludes the fear of soil erosion and suggests the possibility to use drainage methods that can drain excess water with better crop yield.

\subsection{The Effect of Soil Drainage Methods on the Soil Moisture} Content. The highest soil moisture content $(50.7 \%)$ was recorded in the BBF40 drainage method and the lowest (45.5\%) was also from the BBF120 land preparation technique for soil drainage (Figure 6). The moisture content was 


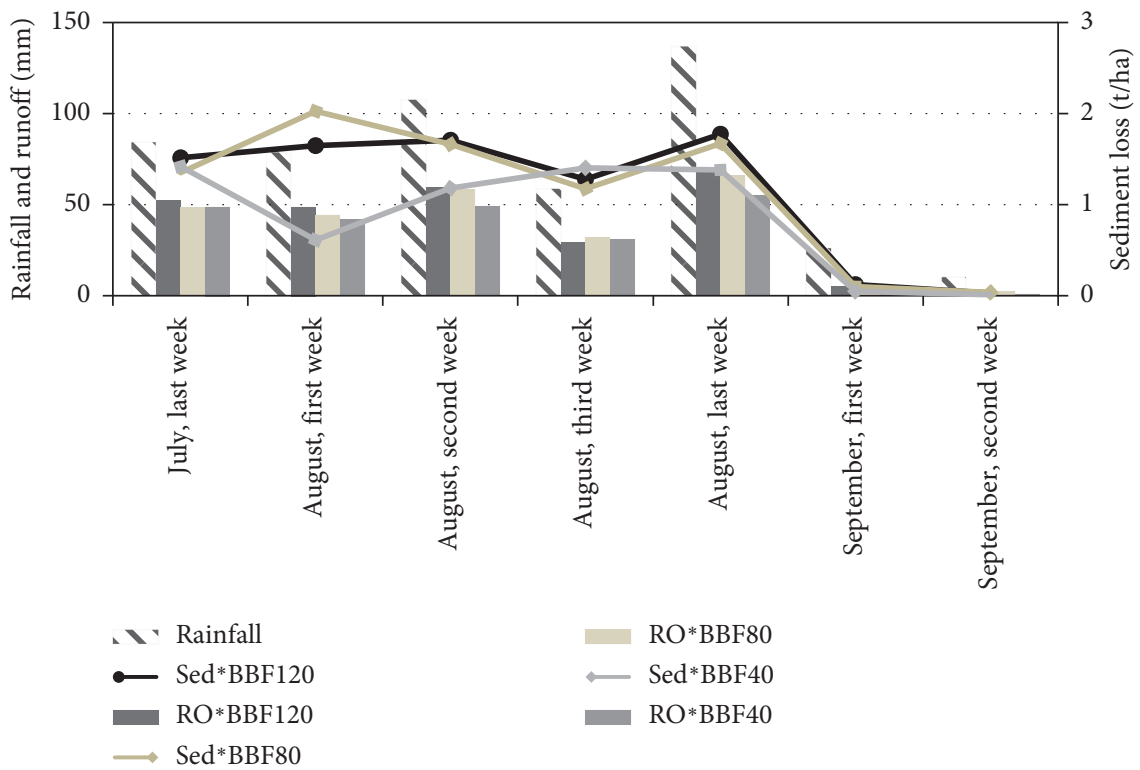

FIGURE 4: The periodical behavior of rainfall, runoff, and sediment yield for the year 2017 growing season (RO: runoff; Sed: sediment).

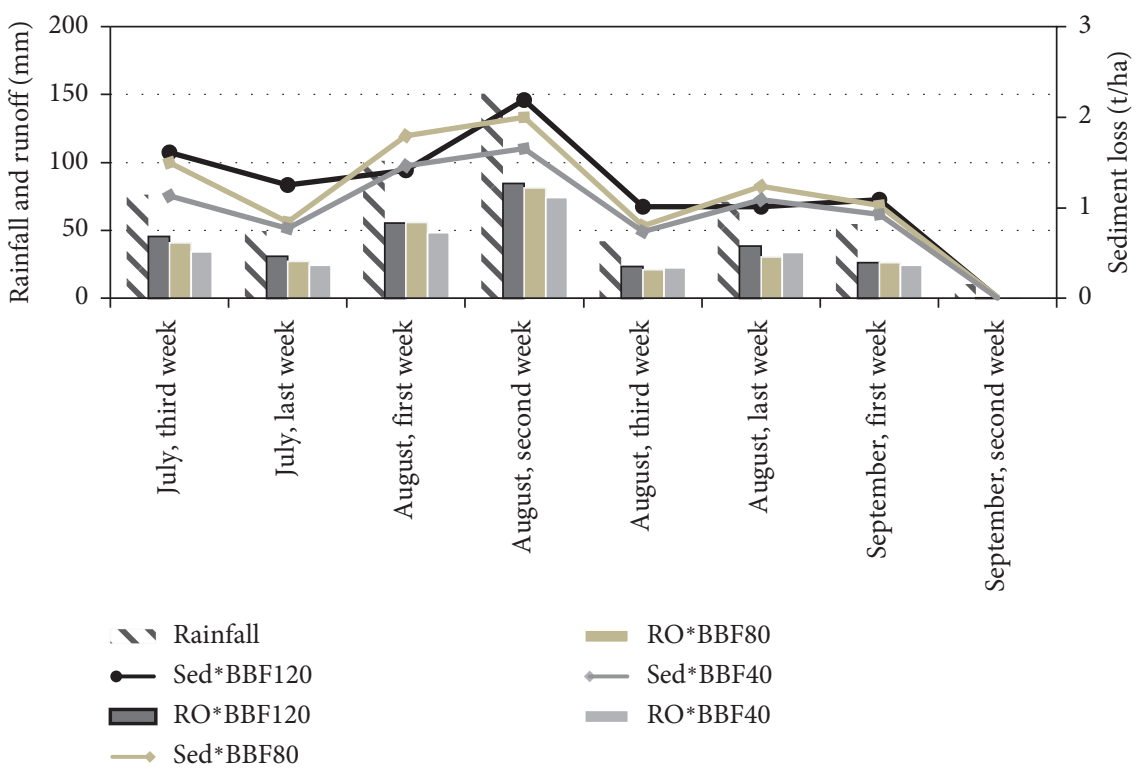

FIGURE 5: The periodical behavior of rainfall, runoff, and sediment yield for the year 2018 growing season (RO: runoff; Sed: sediment).

higher in the bed with smaller bed width (BBF40) since it receives more water per bed due to the case that water infiltrates from the furrow to the bed when it rains. The reduced moisture from $\mathrm{BBF} 120$ in the above case could also be attributed to the reduced number of furrows that causes limitation of water to be stored and infiltrated to the bed side. The real difference in the soil moisture content was observed among the treatments during the periods when there was optimum rainfall that enabled runoff to occur. On an average basis, BBF40 has relatively retained higher moisture content (29\%) than BBF120 which retains $27.4 \%$. This situation might be due to higher infiltration and lower loss of rain water through runoff in BBF40 than BBF120. The lower the capacity of drainage methods to drain excess water, the more the opportunity of water to be stored on created microdepressions of the treatment with higher drainage density [27].

After the period in which rainfall declined, no more excess water occurred; then, accordingly, the difference in the moisture content of the soil for each treatment became insignificant. The lowest moisture content and highest runoff in the high rainy period from BBF120 indicated that this method enhanced surface drainage by removing more excess rainfall than BBF80 and BBF40. 


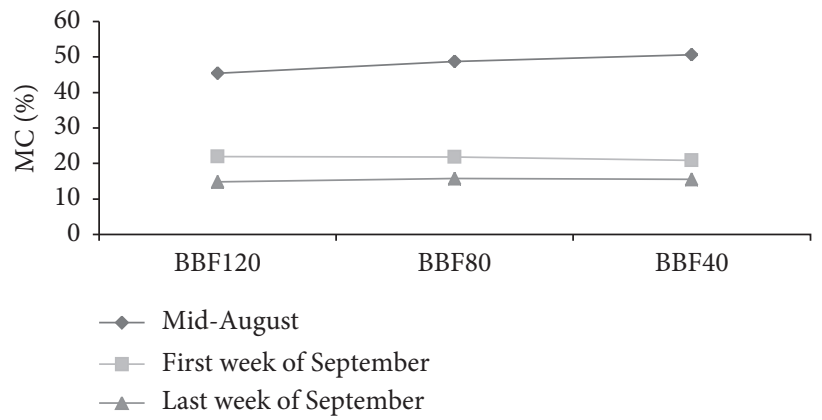

FIGURE 6: Soil moisture content (MC) of each drainage method at different dates of the growing season.

\subsection{The Effect of Soil Drainage Methods on Agronomic Traits of} Wheat. As shown in Table 3, the two years (2017 and 2018) and combined analysis of grain and biomass yields of wheat were significantly affected $(P<0.05)$ by the land preparation methods, while the statistical difference in plant height was insignificant. The grain yield of wheat ranged from 1744 to $2669 \mathrm{~kg} \cdot \mathrm{ha}^{-1}$, while the biomass yield ranged from 4544 to $6704 \mathrm{~kg} \mathrm{ha}^{-1}$. BBF120 treatment gave the highest mean grain yield and biomass of wheat $\left(2669.0 \mathrm{~kg} \cdot \mathrm{ha}^{-1}\right.$ and $\left.6704 \mathrm{~kg} \cdot \mathrm{ha}^{-1}\right)$ followed by BBF80 (2207.5 kg.ha ${ }^{-1}$ and $5847 \mathrm{~kg} \cdot \mathrm{ha}^{-1}$ ), while BBF40 gave the lowest grain yield $\left(1744.30 \mathrm{~kg} \cdot \mathrm{ha}^{-1}\right.$ and $\left.4544 \mathrm{~kg} \cdot \mathrm{ha}^{-1}\right)$, respectively. The relatively low wheat biomass and grain yield performance from BBF40 could be attributed to size of the productive area that is lost for the drainage purpose and the capacity of the method to drain excess water. As shown in Table 4, the highest proportion of productive area to harvestable area is observed from BBF120 (0.82), whereas the lowest proportion (0.55) is from BBF40. It implied that the BBF120 drainage method allows saving $27 \%$ additional productive area when compared with BBF40. When using BBF120, 18\% of the harvestable area is being engaged by furrows, while $45 \%$ of the same area would be engaged by furrows for BBF40. The grain yield and biomass weight per productive area look statistically insignificant (Table 4) for all treatments. It is expected that the drainage method with small bed size and least productive area could give enhanced result than other treatments having more productive area due to the fact that the yield is gained from the same harvestable area. The more facilitation of BBF120 to drain excess water and the advantage of the limiting number of furrows gave an opportunity of saving more land on which crops were grown. Consequently, it has been one reason for the maximum grain yield of wheat recorded from BBF120 than BBF40 over the two experimental years.

Although significantly different biomass and grain yields were observed among treatments, the overall yield performance in this study looks little bit low compared with breeders' yield (3.0-3.4 ton/ha in the researchers' field (personal communication))). The reason for the situation is due to that a variety of trial experiments on wheat in this area are not tracked in a similar technique of data collection. In this experiment, the beds were different in size, so taking a sample only on selected beds was impossible; then, the net plot $\left(44 \mathrm{~m}^{2}\right)$ excluding the border effect was harvested for agronomic data analysis. Unlike we did to take harvested data, breeders in that area took a sample on the small size $\left(0.6 \mathrm{~m}^{2} \sim 0.8 \mathrm{~m}^{2}\right)$ or one bed for each treatment during their study with the same test crop. When the area of drainage technology is not taken into account as an agronomic package, the exaggerated yield performance might be reported when converted from small size into a hectare of land; on the contrary, taking the whole plot for data analysis tells the actual yield that would be gained from the farmer's field, but yield looks lower when compared with the data taken from small plot size [28]. As shown in Table 3, BBF120 showed $34.6 \%$ and $17.3 \%$ grain yield advantage of wheat over BBF40 and $\mathrm{BBF} 80$, respectively. As enhanced drainage is a requirement for successful crop production on Vertisol, these methods might improve crop productivity as well.

The area accounted for furrows' making that is not used to raise crops but used to drain excess water for each land drainage method was varied in a range from $18.2 \%$ to $45.5 \%$ of the total cropland (Table 5). When using BBF120, $81.8 \%$ of land was occupied by beds on which crops were grown, while $18.2 \%$ of land was lost to construct furrows for drainage purposes. The land lost due to furrows coupled with the capacity of land preparation methods to drain excess water on flatlands has resulted in lowest grain yield from BBF40 followed by BBF80, but the highest mean grain yield and biomass were observed from BBF120. It is contributed to the unintended saving of more land to raise crops on the land treated with BBF120 which allows better advantage of draining excess rainfall. BBF120 enables to grow crops on additional 27.3\% (Table 5) land when compared with BBF40 that causes significant land loss due to much area engagement by furrows. 
TAвLE 3: Grain yield (kg/ha), biomass (kg/ha), and plant height $(\mathrm{cm})$ of 2017/18 and combined results.

\begin{tabular}{|c|c|c|c|c|c|c|c|c|c|}
\hline \multirow{2}{*}{ Treatments } & \multicolumn{3}{|c|}{2017} & \multicolumn{3}{|c|}{2018} & \multicolumn{3}{|c|}{ Combined } \\
\hline & GY & $\mathrm{BM}$ & $\mathrm{PH}$ & GY & $\mathrm{BM}$ & $\mathrm{PH}$ & GY & $\mathrm{BM}$ & $\mathrm{PH}$ \\
\hline BBF120 & 2734 & 6019 & 76.5 & 2604 & 7389 & 83.5 & 2669 & 6704 & 80.03 \\
\hline BBF80 & 2032 & 4982 & 77.1 & 2383 & 6713 & 82.8 & 2208 & 5847 & 79.97 \\
\hline BBF40 & 1614 & 3815 & 73.1 & 1873 & 5273 & 79.1 & 1744 & 4544 & 76.13 \\
\hline $\mathrm{CV}(\%)$ & 18.35 & 9.38 & 2.8 & 8.63 & 7.23 & 7.23 & 14.09 & 17.51 & 5.3 \\
\hline $\operatorname{LSD}(\alpha=5 \%)$ & 884.78 & 1050 & NS & 447.51 & 1060 & NS & 387.83 & 1240 & NS \\
\hline
\end{tabular}

GY: grain yield; BM: biomass; PH: plant height; NS: not significant.

TABLE 4: Grain yield $\left(\mathrm{g} / \mathrm{m}^{2}\right)$ and biomass $\left(\mathrm{g} / \mathrm{m}^{2}\right)$ per productive area for each growing season and the proportion of productive area to harvestable area.

\begin{tabular}{|c|c|c|c|c|c|c|c|}
\hline \multirow{2}{*}{ Treatment } & \multicolumn{2}{|c|}{2017} & \multicolumn{2}{|c|}{2018} & \multicolumn{2}{|c|}{ Combined } & \multirow{2}{*}{$\mathrm{PA} / \mathrm{HA}$} \\
\hline & GY & $\mathrm{BM}$ & GY & $\mathrm{BM}$ & GY & $\mathrm{BM}$ & \\
\hline BBF120 & 334.18 & 735.60 & 318.23 & 903.09 & 326.21 & 819.34 & 0.82 \\
\hline BBF80 & 279.46 & 684.95 & 327.61 & 923.03 & 303.53 & 803.99 & 0.73 \\
\hline BBF40 & 295.88 & 699.38 & 343.70 & 966.74 & 319.79 & 833.06 & 0.55 \\
\hline CV (\%) & 16.24 & 8.58 & 8.97 & 6.37 & 13.81 & 17.82 & - \\
\hline $\operatorname{LSD}(\alpha=5 \%)$ & NS & NS & NS & NS & NS & NS & - \\
\hline
\end{tabular}

GY: grain yield; BM: biomass; PA: productive area; NS: not significant; HA: harvestable area.

TABLE 5: Land proportion used for growing crops and making furrows for different soil drainage methods.

\begin{tabular}{lcccc}
\hline Treatments & $\begin{array}{c}\text { Harvestable experimental } \\
\text { area }\left(\mathrm{m}^{2}\right)\end{array}$ & $\begin{array}{c}\text { Productive area (crops growing } \\
\text { on) }\left(\mathrm{m}^{2}\right)\end{array}$ & $\begin{array}{c}\text { Lost area (occupied by } \\
\text { furrow) }\left(\mathrm{m}^{2}\right)\end{array}$ & $\begin{array}{c}\text { Lost area (nonproducing } \\
\text { area) }\end{array}$ \\
\hline BBF120 & 44 & 36 & 8 & 18.2 \\
BBF80 & 44 & 32 & 12 & 27.3 \\
BBF40 & 44 & 24 & 20 & 45.5 \\
\hline
\end{tabular}

\section{Conclusion}

The rainfall of about $55.05 \%, 51.45 \%$, and $48.07 \%$ was converted into runoff from BBF120, BBF80, and BBF40, respectively. So, the runoff coefficient was accounted for more than $50 \%$ of the seasonal rainfall for the first two drainage methods. This indicates the capacity to drain excess water and feasibility of water harvesting systems for irrigation purpose during early harvesting periods. The treatments resulted in significantly different runoff volumes in that BBF120 and BBF80 can save more land on which crops can grow well and induce more excess water to enhance surface drainage than BBF40. The proportion of productive area to harvestable area also indicated the possibility of saving more productive area when implementing BBF120 than the others. These factors contributed to the significant increment of grain and biomass yield of wheat grown using this drainage method. On the contrary, it was observed that all drainage methods showed a tolerable tendency to cause soil loss in the study area.

The finding, in general, revealed that BBF120 gave the highest mean grain yield and biomass of wheat; and it could potentially drain excess rainfall without causing significant soil loss. The capacity of draining more runoff is desirable to tackle the major problem of the study area which is surface waterlogging. So, BBF120 is the best option for draining excess runoff and accordingly maximizing crop yields of wheat. Besides, further study is required on water harvesting systems to enhance Vertisol productivity through using drained water for irrigation in the study area and other eastern Amhara highland areas with a similar farming system and agroecology.

\section{Abbreviations}

ANOVA: Analysis of variance

BBF: Broad bed and furrow

$\mathrm{CV}: \quad$ Coefficient of variation

LSD: $\quad$ Least significant difference

RCBD: Randomized complete block design

SAS: $\quad$ Statistical Analysis System.

\section{Data Availability}

The rainfall, runoff, sediment, and agronomic data used to support the findings of this study are included within the article.

\section{Conflicts of Interest}

The authors declare that there are no conflicts of interest.

\section{Authors' Contributions}

ML carried out the field work, performed the statistical analysis, and drafted the manuscript. WA carried out the field work and contributed to the write-up of the 
manuscript. TT coordinated the study and contributed to the write-up of the manuscript. SB carried out the field work and contributed to the write-up of the manuscript. All authors read and approved the final manuscript.

\section{Acknowledgments}

The authors are grateful to Mr. Mohamed Yesuf for his valuable effort to carry out the field experiment and careful data collection. They are also pleased to acknowledge Sirinka Agricultural Research Center for its continuous follow-up for the field works.

\section{References}

[1] S. C. Jutzi, "Management of vertisols in sub-saharan Africa," in Proceedings of a Conference Held at ILCA, Addis Ababa, Ethiopia, September 1988.

[2] T. Debele and H. Deressa, "Integrated management of Vertisols for crop production in Ethiopia: a review," Journal of Biology, Agriculture and Healthcare, vol. 6, no. 24, pp. 2224-3208, 2016.

[3] G. Asamenew, H. Beyene, W. Negatu, and G. Ayele, "A survey of farming systems of Vertisol areas of the Ethiopian highlands," in Improved M Anagement of Vertisols for Sustainable Crop and Livestock Production in the Ethiopian Highlands: Synthesis Report of 1986-92. Technical Committee of the Joint Vertisol Project, Addis Abeba, Ethiopia, T. Mamo, A. Astatke, K. L. Srivastana, and AsgelilDibabe, Eds., pp. 29-49, FAO, Addis Ababa, Ethiopia, 1993.

[4] L. Haque, "Use of legume biological nitrogen fixation in crop and livestock productionsystems," in Biological Nitrogenfixation and Sustainability of Tropical Agriculture, K. Mulongoy, M. Gueye, and D. S. C. Spencer, Eds., pp. 423-437, A Wiley Saye Co-publication, Hoboken, NJ, USA, 1992.

[5] M. Tekalign and I. Haque, "Potassium status of some Ethiopian soils," East AfricanAgriculture and Forestry Journal, vol. 53/3, pp. 123-130, 1988.

[6] A. Amsalu and J. De Graaff, "Determinants of adoption and continued use of stone terraces for soil and water conservation in an Ethiopian highland watershed," Ecological Economics, vol. 61, no. 2-3, pp. 294-302, 2007.

[7] W. Bewket, "Land cover dynamics since the 1950s in Chemoga watershed, Blue Nile basin, Ethiopia," Mountain Research and Development, vol. 22, no. 3, pp. 263-269, 2002.

[8] A. D. Zegeye, Extent and Impact of Gully Erosion in a Watershed in the Sub Humid Ethiopian Highlands, Cornell University, Ithaca, NY, USA, 2016.

[9] S. C. Jutzi, F. M. Anderson, and A. Astatke, "Low-cost modifications of the traditional Ethiopian tine plough for land shaping and surface drainage of heavy clay soils: preliminary results from on-farm verification trials," in Proceedings of a Conference at ILCA, pp. 28-31, Addis Ababa, Ethiopia, August-September 1987.

[10] R. J. Cook and R. J. Veseth, Wheat Health Management, APS Press, St. Paul, MN, USA, 1991.

[11] Y. Assen, D. Debele, and A. Gorfu, "Evaluation of the effects of surface drainage methods on the yield of bread wheat on vertisols in Arsi zone," in Proceedings of the Eleventh Regional Wheat Workshop for Eastern, Central and Southern Africa, pp. 18-22, Addis Ababa, Ethiopia, September 2000.
[12] M. Mekonen, K. Tesfaye, and W. Bayu, "Soil drainage and nutrient management to improve productivity of waterlogged Vertisols for small-scale farmers," Engineering International, vol. 1, no. 2, 2013.

[13] G. K. McDonald and W. K. Gardner, "Effect of waterlogging on the grain yield response of wheat to sowing date in southwestern Victoria," Australian Journal of Experimental Agriculture, vol. 27, no. 5, pp. 661-670, 1987.

[14] S. Rajaram and M. Thijssen, "Waterlogging in wheat: germplasm evaluation and methodology development," in Proceedings of the Regional Wheat Workshop: For Eastern, Central and Southtern Africa, pp. 16-19, Nakuru, Kenya, September 1991.

[15] T. Erkossa, K. Stahr, and T. Gaiser, "Effect of different methods of land preparation on runoff, soil and nutrient losses from a Vertisol in the Ethiopian highlands," Soil Use and Management, vol. 21, no. 2, pp. 253-259, 2005.

[16] A. Astatke and M. A. Jabbar, "Low-cost animal drawn implements for vertisol management and strategies for land use intensification," in The Sustainable management of Vertisols, pp. 189-202, CABI in Association with IWMI, Bangkok, Thailand, 2001.

[17] A. A. Wubie, "Review on vertisol management for the improvement of crop productivity in Ethiopia," Journal of Biology, Agriculture and Healthcare, vol. 5, no. 12, pp. 92-103, 2015.

[18] I. Haque, M. Abebe, T. Mamo, and A. Dibabe, "Nutrient management," in Improved Management of Vertisols for Sustainable Crop-Livestock Production in the Ethiopian Highlands: Synthesis Report 1986-92. Technical Committee of the Joint Vertisol Project, pp. 51-74, ILCA, Addis Ababa, Ethiopia, 1993.

[19] W. Asnakew, M. Tekalign, B. Mengesha, and A. Tefera, "Soil fertility management studies on wheat in Ethiopia," in Wheat Research in Ethiopia: IAR/CIMMYT, Addis Ababa, Ethiopia, 1991.

[20] T. Getaw, Farming Systems of Delanta District and Farmers Participatory Research Interventions: Result of Field Visits and Research Proposal, Sirinka Agricultural Research Center in collaboration with Oxfam-GB Delanta Project, Sirinka, Ethiopia, 2000.

[21] Z. Adimassu, K. Mekonnen, C. Yirga, and A. Kessler, "Effect of soil bunds on runoff, soil and nutrient losses, and crop yield in the central highlands of Ethiopia," Land Degradation \& Development, vol. 25, no. 6, pp. 554-564, 2014.

[22] A. C. Guzha, "Effects of tillage on soil microrelief, surface depression storage and soil water storage," Soil and Tillage Research, vol. 76, pp. 105-114, 2004.

[23] G. Govers, I. Takken, and K. Helming, "Soil roughness and overland flow," Agronomie, vol. 20, pp. 131-146, 2000.

[24] M. J. Lindstrom, W. B. Voorhees, and C. A. Onstad, "Tillage system and residue cover effects on infiltration in northwestern Corn Belt soils," Journal of Soil and Water Conservation, vol. 39, no. 1, pp. 64-68, 1984.

[25] J. Lipiec, J. Kus, A. Słowin'ska-Jurkiewicz, and A. Nosalewicz, "Soil porosity and water infiltration as influenced by tillage methods," Soil and Tillage Research, vol. 89, pp. 210-220, 2006.

[26] H. Hurni, "Land degradation, famine, and land resource scenarios in Ethiopia," in World Soil Erosion and Conservation, pp. 27-61, Cambridge University Press, Cambridge, UK, 1993. 
[27] L. Zhao, X. Liang, and F. Wu, "Soil surface roughness changes and its effect on runoff and erosion on Loess Plateau of China," Journal of Arid Land, vol. 6, pp. 400-4009, 2014.

[28] S. Jearakongman, S. Immark, A. Noenplub, S. Fukai, and M. Cooper, "Effect of plot size on accuracy of yield estimation of rainfed lowland rice genotypes with different plant heights and grown under different soil fertility conditions," Plant Production Science, vol. 6, no. 1, pp. 95-102, 2003. 